\title{
The Anthropogenic Geomorphology of the New Suburbs, East of Greater Cairo, Egypt
}

\author{
Amr Mohamed Sabry Mahsop Saleem*
}

\begin{abstract}
The Greater Cairo (GC) is one of the largest urban clusters in the world. Basiclly, it contains three interlocked cities including Cairo City (the capital). In the last two decades, many new suburbs were constructed to the east of the old Cairo City. The current study investigates recent urbanization of the new suburbs and its impacts on natural landscape-geomorphology. A series of optical satellite images are utilized to quantify land-cover changes from 2000 to 2017. Detailed field studies were carried out. These field studies allow checking remotely sensed data and observing human-induced landforms. The human activities (urban growth) alter the native geomorphology, mainly drainage basins (wadis). Two applied case studies have been carried out. These applied case studies probe the flash flood risk in the New Cairo City and the New Adminstrative Capital, and demonstrate the land subsidence in Madinty suburb. [Bul. Soc. Géog. d'Égypte, 2018, 91: 1-28]
\end{abstract}

Keywords: Greater Cairo, Man-made Landforms, Remote Sensing, GIS, Field Works, Hazards.

\section{Introduction}

Today Man acts as a third geomorphologic agent in modern geomorphological processes (Jialin et al., 2017). The anthropogenic geomorphology is a discipline which comprises a wide range of surface landforms, extremely diverse in origin and in purpose, created by the operation of human society (Szabo, 2010). It is an emerging branch of geomorphology that focuses on humans as agents of chang (James et al., 2013). In terms of land use, the urbanization process (i.e. urban expansion) prominently impacts landscape, which is termed urbanogenic (Szabo, 2010; Lorant, 2012).

The interaction of human and natural landscape-landforms is attested back to early civilizations. For example Kom el-Dahab (the Hill of Gold) hosted early Roman town in Lake Menzaleh, Nile Delta (Marouard, 2014). In Aeterna Urbs (i.e. historical Rome), Man has continuously modified the drainage system and local topography as early as 3000 years before present (Del Monte et al., 2016).

\footnotetext{
* Department of Geography, Faculty of Arts, Ain Shams University, Cairo, Egypt.
} For Correspondence: e-mail: amr_saleem@art.asu.edu.eg 
Several investigations have looked at modern urbanization and the impact that it has left on the natural landscape and geomorphology. Cisma (2010) identified geomorphic impacts in response to the urbanization process (i.e. cutting the loess hills and volcanic tuffs in some Hungarian villages). Practically Mohapatra et al. (2014) utilized Landsat images to quantify urban expansion in Gwalior City, central India. In four decades, a threefold increase of built up area has caused a significant impact on the main geomorphologic units such as pediplains and hills. Yi et al. (2016) quantified changes in landscape-land use in the Mentougou mountainous area west of Beijing City. About $74 \%$ of new built up area was classified as cropland. This conversion profoundly influenced the landscape patterns of the plain sub-region.

The anthropogenic geomorphology is related to applied geomorphology (Cooke et al., 1982; Szabo, 2010). That is, many aspects of geomorphological hazards and environmental problems occur in urbanized areas, such as flood hazard assessment (e.g. Bathrellos et al., 2016; Costache and Zaharia, 2017; Al-Awadhi et al., 2017), land subsidence (e.g. Chen et al., 2017), as well as the selection of waste disposal sites (e.g. Adeli and Khorshiddoust, 2011).

The current study aims to investigate the man-made landforms and two applied case studies (built up area vulnerability to flash flood hazard and land subsidence of a new residential suburb), within new suburbs, east side of the Greater Cairo (GC). Today the GC metropolitan is among the top ten world's largest agglomoration cities, with around 20 million inhabitants (World Urbanization Prospect, 2018). It has experienced a high urbanization rate and significant modification of natural landscape-landforms, specifically on its eastern margin.

\section{Study Area}

According to Sims (2010) the Greater Cairo region (GC) covers a total area of $4,376 \mathrm{~km}^{2}$. It includes three main cities (i.e. traditionally GC super city including Cairo City, Giza City and Shubra al-Khayma City), peri-urban centers and Greater Cairo's Desert (i.e. ten new towns and private residences). Many previous studies deal with urban growth in GC however, the anthropogenic geomorphology perspective was not considered. The current study focuses on three new settlements being constructed in the desert east of Cairo City, namely New Cairo City (NCC), Madinty and New Administrative Capital (NAC), plus the eastern part of Madinet Nasr and ElNuzha districts (i.e. two marginal neighborhoods that belonged to the old 
Cairo City). These settlements spread over approximately one thousand square kilometers, well determined by the Cairo-Suez highway in the north and the Cairo-Sokhna highway in the south, and crossed by the old ring road and the regional ring road (Figure 1).

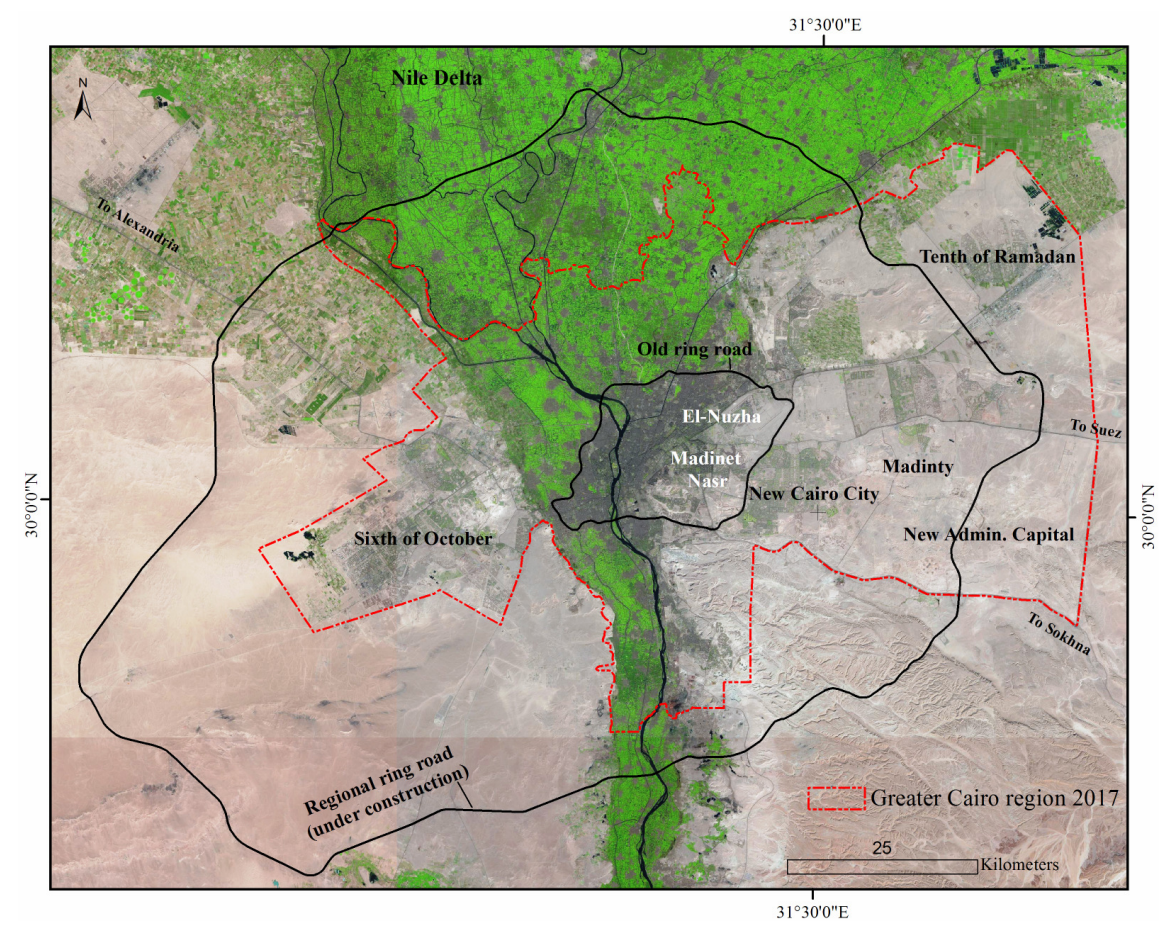

Figure 1. The Greater Cairo Region.

\section{1) Geology and Geomorphology}

The study area occupies the desert east of the Nile fluvial plain where old Cairo City is found. The oldest exposed rocks in the study area dated to the Late Eocene, and they are represented by the Maadi Formation and Anqabiyah Formation that appear in the southern part and two outcrops of Gabal Anasuri and Gabal El-Anqabiyah (Figure 2). According to Moustafa et al. (1991) claystone and marls are characteristic for the Upper Eocene east of Cairo City. The Oligocene sediments unconformably overlie the Upper Eocene rocks and comprise the Gabal Ahmar Formation which is made up of sandstones and gravels with silicified pipes and tree trunks. The Gabal Ahmar Formation dominates a wide area of the NCC, typically in the Petrified Forest. Oligo-Miocene basalt flows cap the Oligocene sediments in some parts (Moustafa and Abd-Allah, 1991), and they are scattered in some localities, mainly close to the Cairo-Suez highway (Figure 2). The exposed 
Miocene rocks in the study area are categorized as Middle Miocene marine deposits (Homath Formation), and Upper Miocene non-marine deposits (Hagul Formation).

According to Said (1962) and the geologic map of Greater Cairo two main sets of normal faults oriented E-W and NW-SE are defined in the study area. Also, three NW-SE anticlinal structures affect the upper Eocene rocks (Figure 2).

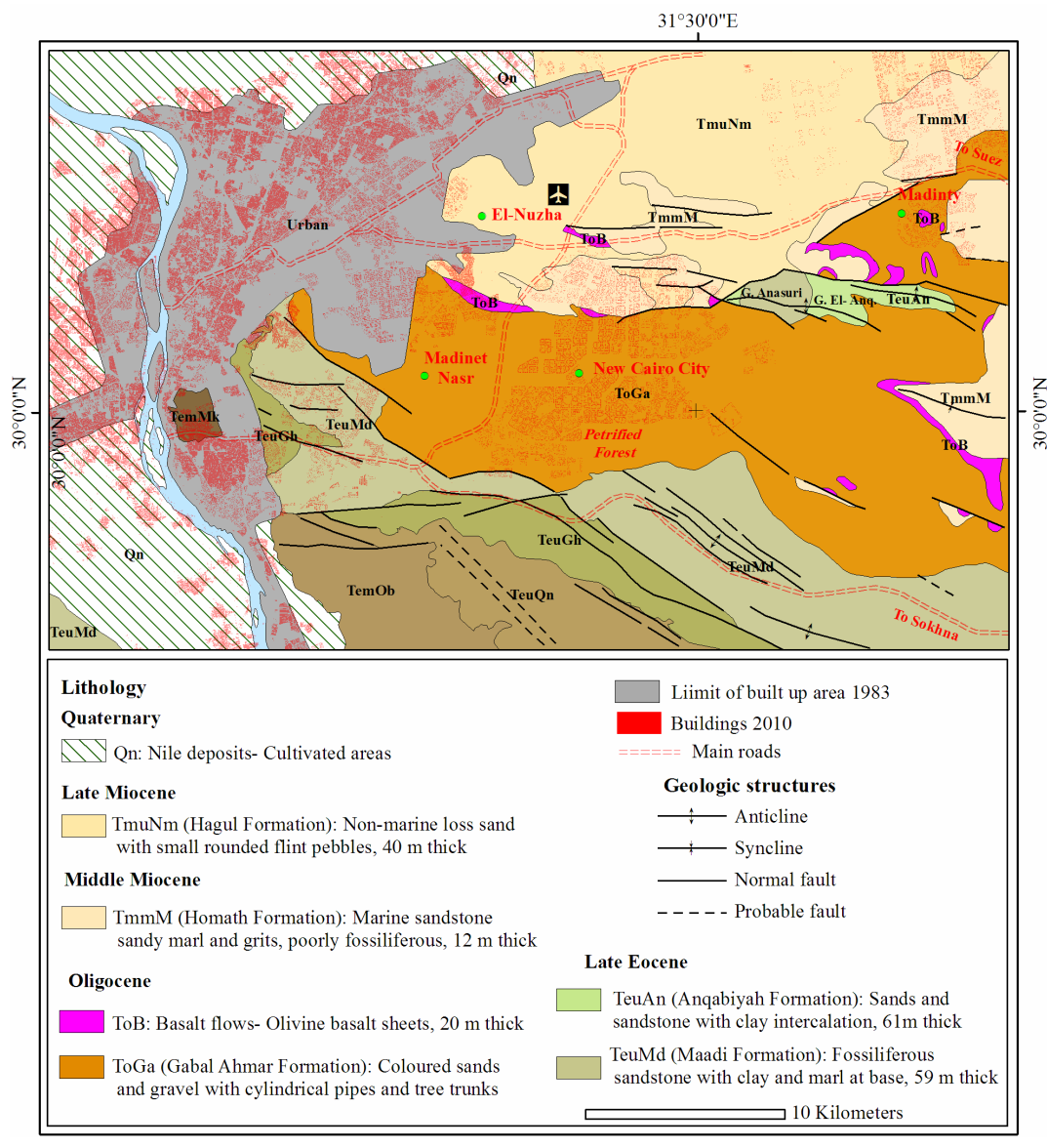

Figure 2. Geological map of Greater Cairo

(Modified after the Egyptian Geological Survey and Mining 1983)

Geomorphologically, wadis are the main characteristic feature of Greater Cairo's Eastern Desert. The current study area of interest occupies the whole fifteen drainage basins, and partly intersects two large drainage basins (i.e. around the third upstream of Wadi Degla and three quarters of Wadi Aljindali). The basic morphometric properties of seventeen drainage 
basins and wadi networks are measured and calculated as shown in Table (1) and Figure (3a).

\section{- Size properties (basin area, basin length and stream order):}

Runoff generation and the frequency of floods are directly correlated with drainage area (Goodwin and Tarboton, 2004). The areas of drainage basins range between $11 \mathrm{~km}^{2}$ (Wadi Idam) and $213 \mathrm{~km}^{2}$ (Wadi Aljindali). Among all basins eleven are less than $50 \mathrm{~km}^{2}$. All wadis of each basin are ordered based on Strahler's method (1957). The order of outlet wadis (which ranges between 3 and 6 in the study area) indicates the basin size. However, basin magnitude (i.e. the number of first order wadis) is a more discerning measure of size (Goodwin and Tarboton, 2004), (Table 1).

\section{- Shape properties (elongation ratio):}

The elongation ratio is defined as the ratio between the diameter of a circle which has the same area as the drainage basin and the maximum basin length (Schumm, 1956). Its maximum value equal (1) indicates a typical circle shape. The elongation ratio has an important hydrological consequence, as precipitation delivered during a storm in highly elongated basins (less circular) has to travel a wide distances to reach the basin outlet (Kumar, 2014). Applying elongation ratio in the study basins indicates that Wadi Halazuni is the most elongated basin (0.36). Among all, eleven basins have values less than 0.49 (Table 1).

\section{- Relief ratio:}

Absolute relief $(\mathrm{R})$ is the height difference between the highest upstream point and the lowest outlet point within the drainage basin. Schumm (1956) represents the relief ratio $(\mathrm{Rr})$ as relief $(\mathrm{R}) /$ Basin length to neutralize the size effect. The study basins have a relief ratio between 0.008 and 0.021 , with an average of 0.014 . The high relief ratio indicates surface denudation and it is directly proportional to flooding and inversely to the time of concentration (Bajabaa et al., 2013).

\section{- Slope:}

In arid lands, key runoff-producing areas tend to be found on steep slopes (Wainwright and Bracken, 2011). The slope raster identifies the slope gradient, or rate of maximum change in z-value from each cell of a raster surface (Esri, 2014). SRTM Digital Elevation Model (DEM) is used to create a slope raster map (Figure $3 b$ ). In the study basins, the slopes vary from 0 to $47^{\circ}$. Steep slopes cells correspond to structural landforms (e.g. the fault lines in the upstream of Wadi Aljindali, and anticline structure in the midstream of Wadi Anqabiyah), water divide areas and the sides of trunk wadis (e.g. Wadi Degla, Wadi Halazuni and Wadi Anasuri). 


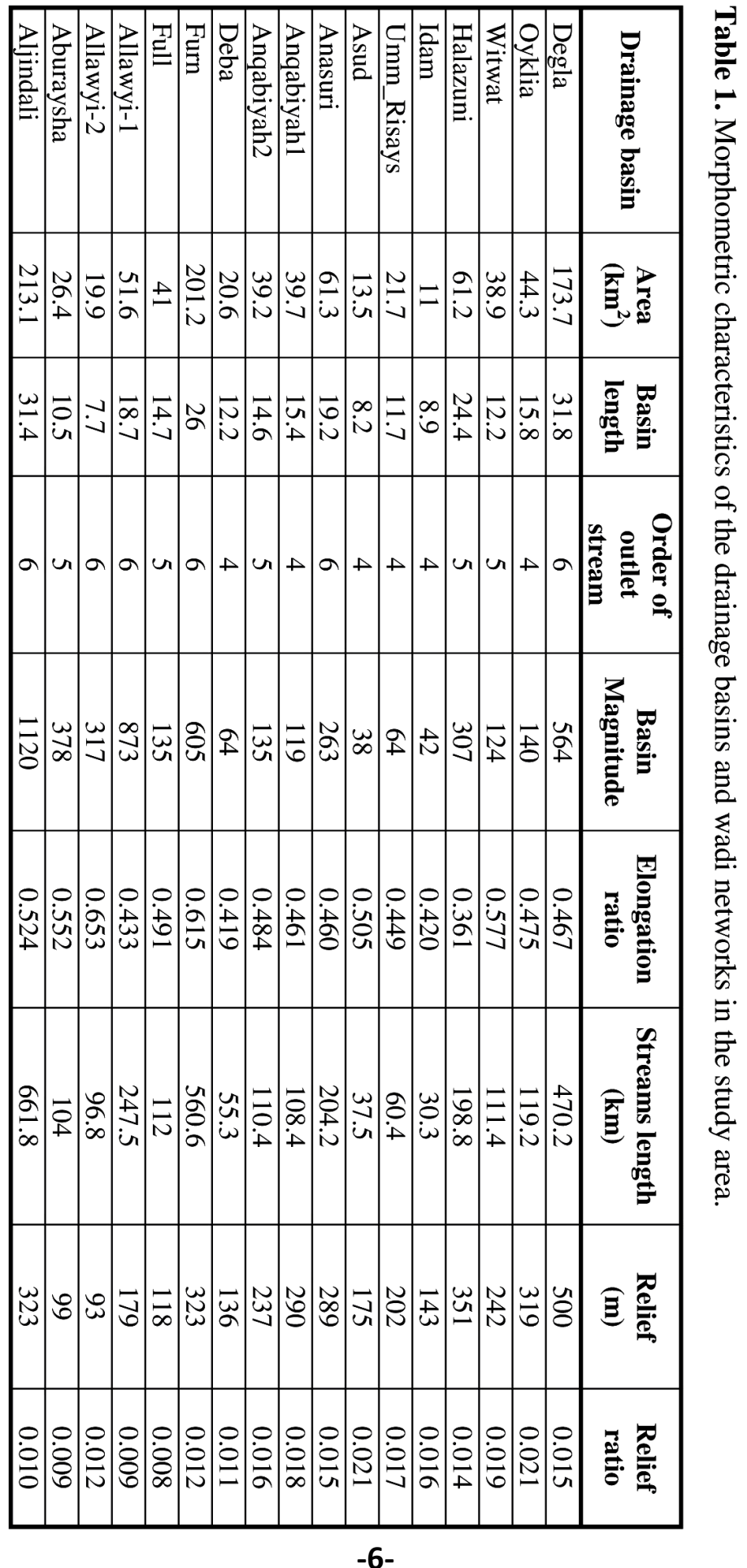




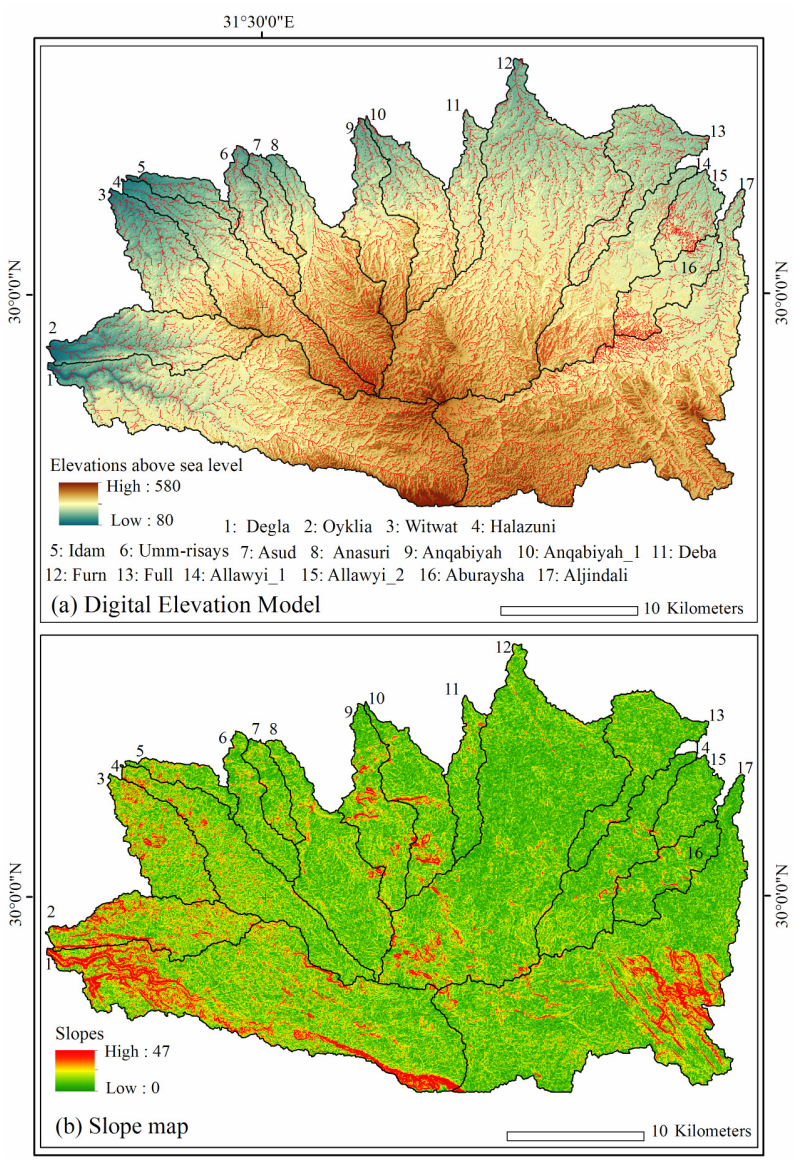

Figure 3. The drainage basins east of Greater Cairo.

\section{2) Urban Growth and Land Cover-Land Use}

Historically, NCC belongs to the second generation of new cities in Egypt. Substantially, it was established with a presidential decree number (\#191) for the year 2000 (Hafez, 2017). Madinty residence was constructed by a private real estate investor. Since 2006 Madinty has expanded to an area of $33 \mathrm{~km}^{2}$. Since 2016, the NAC has been under construction, and this mega project aims to create a new independent capital. The NAC will occupy an approximate area of $440 \mathrm{~km}^{2}$. According to the Egyptian ministry of Housing and Urban Communities, the project will cost $45 \$$ billion and be complete by 2022 .

The urban growth of GC sub-sectors has been quantified in several previous studies through the application of remote sensing techniques. For example, Hereher (2012) estimated the net increase of urban areas in 
Cairo City from $344.4 \mathrm{~km}^{2}$ in 1986 to $460.4 \mathrm{~km}^{2}$ in 1999 . Blasco et al. (2017) measured $274 \mathrm{~km}^{2}$ of newly constructed areas in Greater Cairo region between 1998 and 2010. The transformation to built up area took place on both cultivated land (i.e. alluvial plain) and barren desert. However, less attention is considered about geological and geomorphological impacts of the urban growth. Exceptionally, El-Sawy et al. (2016) use a classified Landsat dataset to estimate the decrease of sedimentary cover in the NCC and surroundings, from $820 \mathrm{~km}^{2}$ in 2003 to $654.6 \mathrm{~km}^{2}$ in 2014 .

The study area consists of four land covers such as built up area, vegetation, water body and barren desert. Housing is a dominant land use in the NCC, and luxury residential parks represent a characteristic housing pattern. The central business district includes many companies, banks, private universities, hospitals and trading malls (Figure 4).

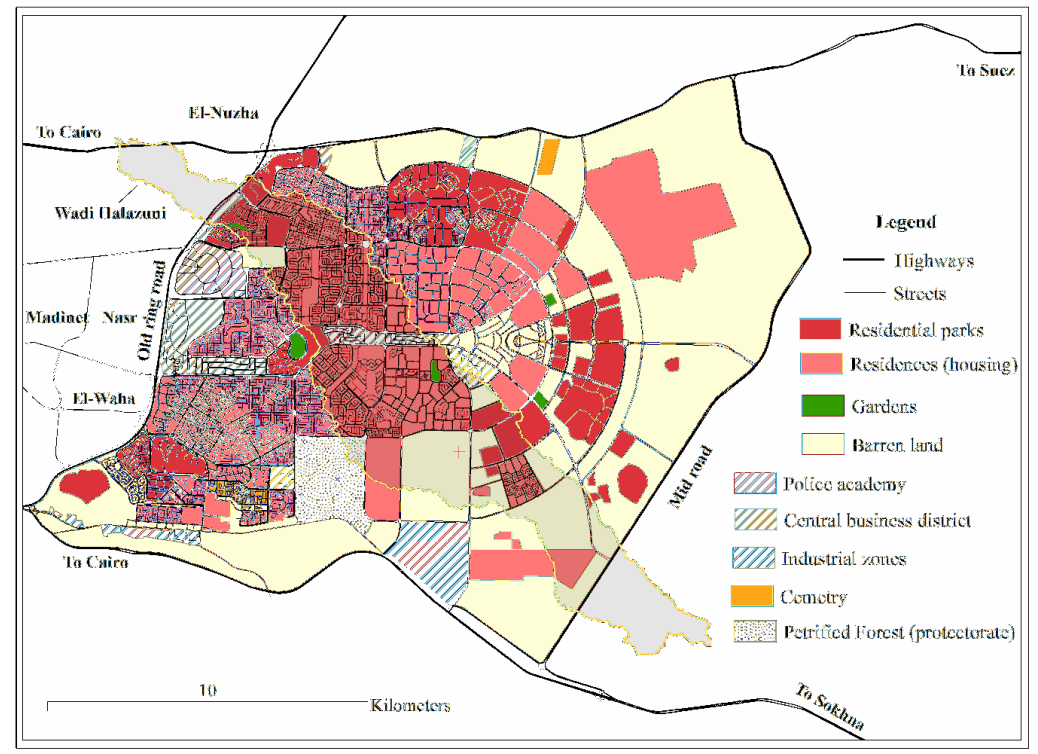

Figure 4. Land use map of the New Cairo City.

\section{Methods}

\section{1) Data Collection}

Various geospatial data are utilized in the current study such as topographic maps (six sheets, scale 1/50,000), a geological map of GC area, a preexisting vector base map of GC, aerial mosaic (captured 1955, scale 1/50,000), SRTM Digital Elevation Model and optical satellite images. The geospatial data preparation was undertaken which includes coregistration, data manipulation, clipping, mosaicking and data storage. 
The Landsat mission provides a large archive of satellite images since 1972 with the operation of the Landsat1. Two Landsat products are used in correspondence to the stages of urban development in the study area (Table 2), Enhanced Thematic Mapper plus (ETM+) onboard Landsat-7 and Optical Land Imager (OLI) onboard Landsat-8. Since June 2015, the European Space Agency provides Sentinel-2 optical images. The Sentinel-2 carries the Multi Spectral Instrument (MSI), operating with thirteen spectral bands (Table 2). The Sentinel-2 products are utilized to observe the most recent changes in the study area.

Ten field trips have been carried out between October 2016 and April 2018. The one day field trips aimed at measure cross profiles, measure detailed geologic sections, collecting notes and collecting sedimentary samples. X-ray diffraction (XRD) analysis performed on collected samples, which precisely defines the non-clay and clay mineral contents.

Table 2. Satellite images used in the current study.

\begin{tabular}{|c|c|c|c|}
\hline Satellite & Sensor & Image (ID) & $\begin{array}{c}\text { Spectral resolution - spatial } \\
\text { resolution (meters) }\end{array}$ \\
\hline Landsat 7 & ETM+ & $\begin{array}{l}\text { LE71760392000316EDC00 } \\
\text { Acquisition-date: } 11 / 11 / 2000\end{array}$ & $\begin{array}{l}\text { Bands }(1-\mathrm{B}, 2-\mathrm{G}, 3-\mathrm{R}, 4-\mathrm{NIR} \\
\text { and } 5-\mathrm{SWIR})=30 \mathrm{~m} \\
\text { Band ( } 8 \text {-Panchromatic) }=15 \mathrm{~m} \\
\text { (used in sharpening multi } \\
\text { spectral image) } \\
\text { Band (6 Thermal) }=120 \mathrm{~m}\end{array}$ \\
\hline Landsat 8 & OLI & $\begin{array}{l}\text { LC81760392013119LGN01 } \\
\text { Acquisition-date: 29/4/2013 }\end{array}$ & $\begin{array}{l}\text { Bands (2-B, 3-G, 4-R, 5-NIR } \\
\text { and 6-SWIR ) = 30 m } \\
\text { Band (8-Panchromatic) }=15 \mathrm{~m} \\
\text { (used in sharpening multi } \\
\text { spectral image) }\end{array}$ \\
\hline Landsat 8 & TIRS & $\begin{array}{l}\text { LC81760392013119LGN01 } \\
\text { Acquisition-date: } 29 / 4 / 2013\end{array}$ & Band $(10-$ Thermal 1) $=30 \mathrm{~m}$ \\
\hline Sentinel-2 & MSI & $\begin{array}{l}\text { L1C_T36RUU_A001019_ } \\
\text { 20150902T084232 } \\
\text { Acquisition-date: } 2 / 9 / 2015\end{array}$ & $\begin{array}{l}\text { Bands: }(2-\mathrm{B}, 3-\mathrm{G}, 4-\mathrm{R} \text { and } 8- \\
\mathrm{NIR})=10 \mathrm{~m} \\
\text { Bands } \quad(5-\mathrm{VNIR}, \quad 6-\mathrm{VNIR},\end{array}$ \\
\hline Sentinel-2 & MSI & $\begin{array}{l}\text { L1C_T36RUU_A006453_ } \\
\text { 20160916T121902 } \\
\text { Acquisition-date: 16/9/2016 }\end{array}$ & $\begin{array}{l}\text { 7-VNIR, 8a-VNIR, 11-SWIR } \\
\text { and } 12-\text { SWIR) }=20 \mathrm{~m} \\
\text { Bands ( 9-VNIR and10-SWIR) }\end{array}$ \\
\hline Sentinel-2 & MSI & $\begin{array}{l}\text { L1C_T36RUU_A011744_ } \\
\text { 20170921T084129 } \\
\text { Acquisition-date: } 21 / 9 / 2017\end{array}$ & $=60 \mathrm{~m}$ \\
\hline
\end{tabular}




\section{2) Remote Sensing and GIS Analyses}

The remote sensing and GIS tools are widely used in anthropogenic geomorphology studies (Loughland et al., 2012; Mohaptra et al., 2014; Yietal., 2016). In the current study, these techniques are used in geomorphological mapping and morphometric analyses of the wadis, extraction of the land covers, monitoring the man induced changes of the natural landscape and GIS-based risk analysis of the flash floods.

\section{a. Automatic Extraction of the wadis}

The Esri's Arc GIS hydrological model is applied based on SRTM Digital Elevation Model. This model use a series of steps that perform a raster fill sink, create a raster of flow direction and create a raster of flow accumulation. This information can be used to define watershed (i.e. drainage basin boundaries) and stream networks (Esri, 2012). Also, topographic maps, aerial mosaic, ETM+ image and Setinel-2 image are used in combination to digitize trunk wadis in a polygon layer. The basic morphometric parameters of the drainage basins are calculated and stored in a geodatabase.

\section{b. Spectral Indices}

The spectral index comprises algebraic calculations of multispectral bands. It aims at automatic extraction of a specific feature (i.e. pixel-based feature in the satellite image). The spectral indices allow one to extract land covers in the study area at various dates, such as built up area, vegetation cover and water body. The current study utilizes the following spectral indices:

\section{- Normalized Difference Vegetation Index (NDVI)}

The Normalized Difference Vegetation Index (NDVI) allows the extraction of vegetation land cover in the study area (i.e. gardens and parks). The NDVI acts in the reflectance contrast of the vegetation (green pigment) in two spectral bands, the high reflectance in the near-infrared band (NIR), and the low reflectance in the red band $(\mathrm{R})$.

The NDVI is expressed as:

$$
(N I R-R) /(N I R+R)
$$

In ETM+ (Landsat7): $\quad$ (band4-Band3) /(band4+Band3)

In OLI (Landsat8): $\quad$ (band5-Band4) /(band5+Band4)

In MSI (Sentinel-2): $\quad$ (band8-band4) /(band8+band4) 
- Modified Normalized Difference Water Index (MNDWI)

Xu (2006) has developed Modified Normalized Difference Water Index as:

$$
\text { (Green-MIR) /(Green+MIR) }
$$

In OLI (Landsat8):

(band3-Band6) /(band3+Band6)

In MSI (Sentinel-2):

$\left(\right.$ band3-Band $\left.11^{10 m}\right) /\left(\right.$ band $3+$ Band $\left.11^{10 m}\right)$, sharpening the SWIR band 11

The MNDWI is typically used to extract water bodies in the urban area because it has the advantage of removing the noise background of the built up area.

\section{- Built-up area indices}

Zha et al., (2003) presented the Normalized Difference Built-up Index (NDBI). Using Landsat-5 TM, the NDBI spectral index was represented as $(M I R-N I R) /(M I R+N I R)$. This index depends on the high reflectance of the built up area in the mid-infrared band (MIR) and the low reflectance in the near-infrared band (NIR).

Several attempts have been to improve the built up area extraction using spectral indices. The Enhanced Built-Up and Bareness Index (EBBI) is the first built-up and bare land index that applies near infrared (NIR), short wave infrared (SWIR) and thermal infrared (TIR) of the Landsat-7 ETM+ (Assyakur et al., 2012). It is applied efficiently to separate built up area and background barren desert in the study area, as:

$$
(S W I R-N I R) / 10 * \sqrt{ }(S W I R+T I R)
$$

In ETM+ (Landsat7): $\quad($ band5-band4) $/ 10 * \sqrt{ }($ band5+band6)

In OLI (Landsat8): $\quad$ (band6-band5) / $10 * \sqrt{ }($ band6+band10)

Angiuli and Trianni (2014) developed the normalized difference spectral vector (NDSV), through the combination of all available bands. Then, they grouped the resulting normalized difference spectral indices. In the current study, the NDSV is applied to extract built up area based on the Sentinel-2 dataset. Specifically, after resampling all the Sentinel-2 bands to $20 \mathrm{~m}$ spatial resolution, the proposed method exploits normalized indexes built considering all possible band pairs, so that multiple indexes are computed at once and included in a vector characterizing each pixel. 
The NDSV provides a vector of values able to fuse at the same time the different spectral feature of an urban pixel. For instance, a typical urban pixel should have a value of the above mentioned NDBI close (ideally, equal to 1), but it could also be characterized by the normalized difference vegetation index (NDVI), because it should have an NDVI value close (ideally, equal) to 0 . Similarly, we can look for urban pixels by considering the modified normalized difference water Index (MNDWI), and looking for locations with a 0 MNDWI value. The NDSV captures all these properties at the same time, enabling a more correct characterization of built-up pixels.

\section{c. Weighted overlay model (WOM)}

The GIS based weighted overly model (WOM) is mainly used for optimal site selection and suitability analysis (Esri, 2011). In the current study, it is dedicated for mapping built up area vulnerable to flash flood hazard, specifically in Wadi Anasuri. The WOM implements two input criteria (i.e. two factors control flooding in wadis), such as the ordered trunk wadis (digitized as polygons) and slope map. These geospatial data sets have a raster format, and are reclassified to meaningful categories.

In the WOM the classes of each criterion are ranked in a range between 1 and 9. The most hazardous class is given a high value and vice versa of the less hazardous class. For example, the highest ordered sixth trunk wadis ranked by 9 and interwadis area ranked by 1 . The same pattern is followed for ranking the slope classes (Table 3). The wadis (criterion) are relatively assigned the highest influence equal to $60 \%$. Finally that yields a flood hazard districting map. The spatial relationship between flood hazard map and housing land use is calculated using zonal statistics in Arc GIS ${ }^{\circledR} 9.3$ spatial analyst tool.

Table 3. The weights of each thematic layer used in the WOM (Wadi Anasuri).

\begin{tabular}{|c|c|c|c|}
\hline Criteria (layer) & Influence value \% & Class & Weight \\
\hline \multirow{7}{*}{$\begin{array}{l}\text { Wadis network- } \\
\text { interwadis }\end{array}$} & \multirow{7}{*}{$60 \%$} & Sixth-ordered wadis & 9 \\
\hline & & Fifth-ordered wadis & 8 \\
\hline & & Fourth-ordered wadis & 7 \\
\hline & & Third-ordered wadis & 4 \\
\hline & & Second-ordered wadis & 3 \\
\hline & & First-ordered wadis & 2 \\
\hline & & Interwadis areas & 1 \\
\hline \multirow{5}{*}{ Slope } & \multirow{5}{*}{$40 \%$} & $0-1.5^{\circ}$ & 1 \\
\hline & & $1.5-3^{\circ}$ & 2 \\
\hline & & $3-5^{\circ}$ & 5 \\
\hline & & $5-9^{\circ}$ & 7 \\
\hline & & $9-25^{\circ}$ & 9 \\
\hline
\end{tabular}

$-12-$ 


\section{Results and Discussion}

\section{1) The Man-made landforms (urbanogenic)}

The man-made landforms can be classified into nine types based on functional morphology, such as urban rural construction morphology and industrial morphology. These types can be divided into man-made accumulation subtype and man-made excavation subtype (Jialin et al., 2017). According to Szabo (2010) the anthropogenic impacts on natural landscape and geomorphology have been identified under specific fields such as mining (montanogenic), industrial (industrogenic), settlement expansion (urbanogenic) and agriculture (agrogenic). The current study focus on the man-made landforms being reshaped mainly by the urbanogenic processes.

\section{a. The New Cairo City and surrounding neighborhoods}

The urban growth of the NCC took place in eight drainage basins, namely, Oyklia, Witwat, Halazuni, Idam, Umm-risays, Asud, Anasuri and Anqabiyah. It tends to be eastward. In general, the whole built up area increased from $3.08 \mathrm{~km}^{2}$ in 2000 to $65.9 \mathrm{~km}^{2}$ in 2017 . Over the same period vegetation cover (representing gardens and parks) increased from $2.6 \mathrm{~km}^{2}$ to $13.9 \mathrm{~km}^{2}$. The urban development of the NCC causes a significant change of natural landscape and geomorphology.

In 2017, about $35 \%$ of the total area of Wadi Halazuni is occupied by gardens, asphalt and buildings (Figure 5). In 2000 both Wadi Anasuri and Wadi Anqabiyah were totally barren, however built up area progressively being increased since 2015. That is attributed to the construction of new housing projects and new roads. A transition from natural landscape to artificial landscape is observed in some peripheral sites, for example AlNargs sub-district neighboring to the Petrified Forest protectorate.

The man-made landforms in the NCC may be classified into two main categories, such as erosional (negative landforms) and depositional (positive landforms). These landforms are found by the means of multi-urbanogenic processes, such as infrastructure-buildings construction, surface leveling, quarrying and waste conglomerations and they are varied in their dimensions and composition (mostly a mixture of artificial and natural materials). The man-made landforms are identified and observed in three sample sites.

\section{- Biet El-Watan district}

In February 2016, The Egyptian ministry of housing has undertaken the foundation of Biet El-Watan residential project. It covers a total area of 31.6

$\mathrm{km}^{2}$, and about $65 \%$ of that occupies the mid-section of Wadi Anqabiyah 
basin. In September 2017 a prominent change of landscape is observed due to the planning of street networks and land parcels. This progressive action causes a wide lowering of the initial surface and a sever destruction of the Gabal Anasuri anticline. Also, the new constructions sprawl on basalt sheets near to the mid road (Figure 6). In Biet El-Watan site some irregular shaped pits appear in the surface. These pits are sand quarries, and their numbers and dimensions are varied on a monthly base (2015-2017). In the field a total volume of quarried sands in a large pit $\left(30^{\circ} 02^{\prime} 6.8^{\prime \prime} \mathrm{N} 31^{\circ} 33^{\prime} 18.1^{\prime \prime} \mathrm{E}\right)$ was estimated to be 3 million cubic meters (May 21, 2017), (Figure 7a).

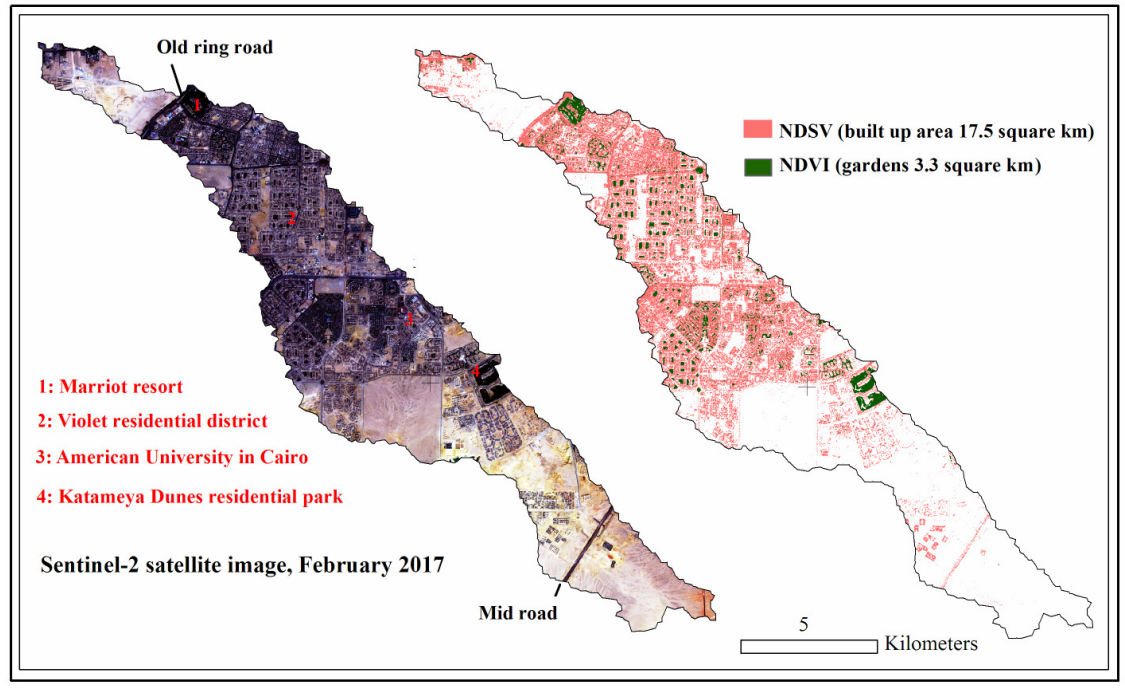

Figure 5. Human occupation in Wadi Halazuni.

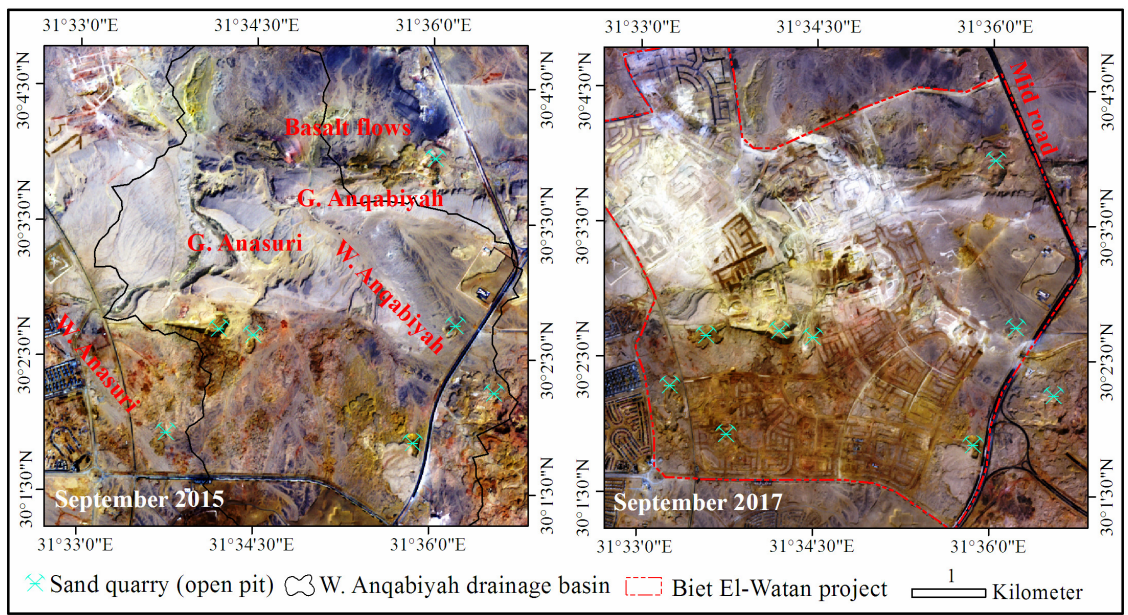

Figure 6. The pre-development urbanization in Biet El-Watan.

\section{$-14-$}




\section{- El-Waha (Madinet Nasr neighborhood)}

El-Waha sub-district is found in the most eastern extent of Madinet Nasr neighborhood, near to the NCC (Figure 1). Since 2013, it has witnessed a progressive urbanization rate, through the construction of new highways $\left(1.3 \mathrm{~km}\right.$ long per $\left.1 \mathrm{~km}^{2}\right)$, new residences, a motel resort and two sporting clubs. Characteristic man-made landforms are observed in El-Waha, such as positive and negative man-made landforms. The positive landforms take a mesa-like form with rounded flat top and steep slope sides. The man-made mesas are mainly composed of excavated sand (Figure $7 \mathrm{~b}$ ). Some of the man-made mesas are extensively used to accumulate household wastes (Figure 7c). The negative man-made landforms comprise three quarries left abandoned along the side of the ring road. Recently, these old quarries re-used to accumulate the sewage of the NCC $\left(30^{\circ} 00^{\prime} 12.6^{\prime \prime} \mathrm{N} 31^{\circ} 23^{\prime} 21.3^{\prime \prime} \mathrm{E}\right)$. The surface area of sewage water was quantified to be $0.02 \mathrm{~km}^{2}$ in February 2017. The discharge of sewage water gives unique micro-scale features such as artificial drain, sandy talus and marsh weeds (Figure 7d).
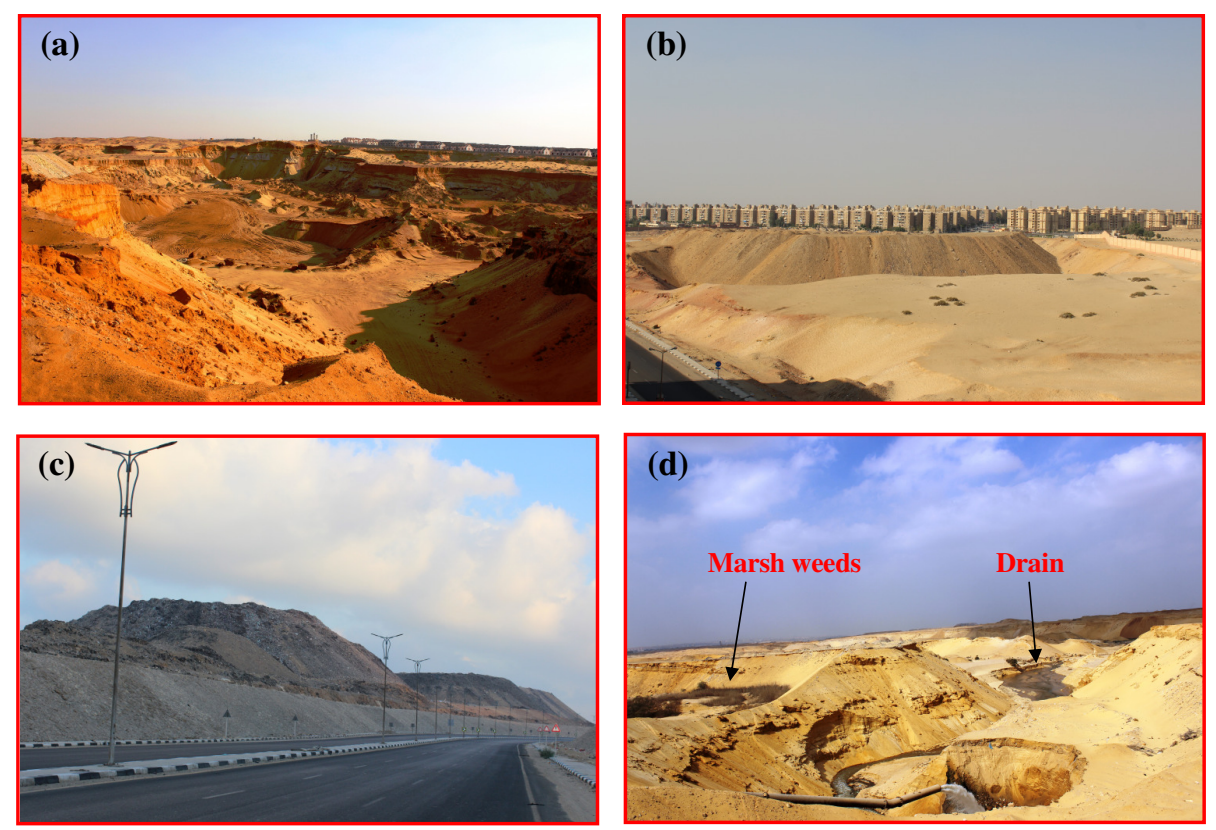

Figure 7. (a) Sand quarry (Biet El-Watan district), (b) Man-made mesa (excavated sand in El-Waha district), (c) Man-made mesas (dumps in El-Waha district), (d) Wastewater discharge (El-Waha district). 


\section{- Cairo International Airport (CAI, El-Nuzha neighborhood)}

Cairo International Airport (CAI) occupies a flood-out terrain of short wadis which slope down from the high terrain north to the Cairo-Suez highway. Historically, the American Bayn Field air-force base was established in this site during the Second World War. As revealed by the 1955 aerial mosaic, CAI (formerly Bayn Field base) was built with two runways. Since then CAI has expanded eastward, specifically through the construction of two new runways (05C-23C operated in 1984) and (05R-23L operated in 2008). The expansion of CAI caused land planation of $24 \mathrm{~km}^{2}$ in the wadis downstream area (Figure 8).

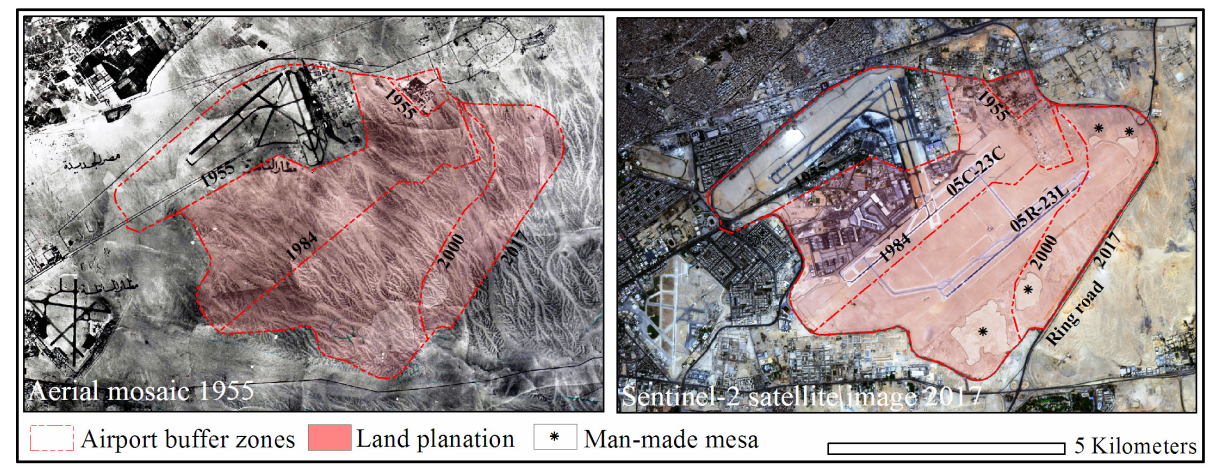

Figure 8. The long term expansion of Cairo International Airport.

\section{b. The New Administrative Capital (NAC)}

$\mathrm{NAC}$ is in the pre-development stage. The foundation of the NAC yields pronounced modification of the natural landscape-landforms. The Sentinel-2 based investigation combined with field work revealed that in September 2015, the natural landscape dominates the study area (Figure 10a). By the next year (September 2016) the transition from physical to artificial landscape took place. The man-made imprints are identified such as reddish streaks found by sealing of surface deposits (Figure 10b) and white patches produced by human activity (i.e. limestone quarries and limestone accumulations used in paving roads and constructions, Figure 9a).

The new artificial landforms comprise the new roads (about $460 \mathrm{~km}$ of new asphalt), four housing neighborhoods, busniess area, El-Masa resort, Siemens electric power station and the new extension of the Katameya airport (Figure 10c). The overall increase in built-up area (buildings and roads) in two years is quantified to be $2.16 \mathrm{~km}^{2}$.

The progressive urbanization process causes a severe degradation of the drainage systems. Wide areas of the wadis are bulldozered (Figure 9b). 
In wadi Allawyi-sub1 (the heart of the NAC), about $60 \%$ of the first order tributaries are totally destroyed, which equal $77 \mathrm{~km}$.

The cut of natural land is identified in many sites, such as the new tunnel cross the regional ring road $\left(29^{\circ} 5^{\prime} 22.03^{\prime \prime} \mathrm{N} 31^{\circ} 41^{\prime} 54.00^{\prime \prime}\right.$ E) and a parcel (equals $\left.15000 \mathrm{~m}^{2}\right)$ will be used to build a new library $\left(29^{\circ} 54^{\prime}\right.$ $41.07^{\prime \prime} \mathrm{N} 31^{\circ} 41^{\prime} 05.56^{\prime \prime} \mathrm{E}$ ). In contrast, the land infill is found where the new roads under construction cross the trunk wadis. In the field, cross sections are used in three sites to observe the artificial cut and infill processes (Figure 12).

\section{c. Madinty}

Madinty occupies the downstream areas of both Wadi Anqabiyah-1 and Wadi Deba. In February 2017, the total built up area (buildings and streets) in Madinty equals $5.4 \mathrm{~km}^{2}$ (Figure 11d). In Madinty, the architecture landscaping is compatible with natural topography. For example, the residence has been designed with many culverts and embankments along trunk wadis (Figure 9c). However, some wadis exhibit an angular-shaped cross section due to man-made modification (Figure 12). Some wadis are completely blocked by artificial fillings, such as the main trunk of Wadi Deba, near to Cairo-Suez highway (30 06' 58.29" N 31 39' 2.02" E).
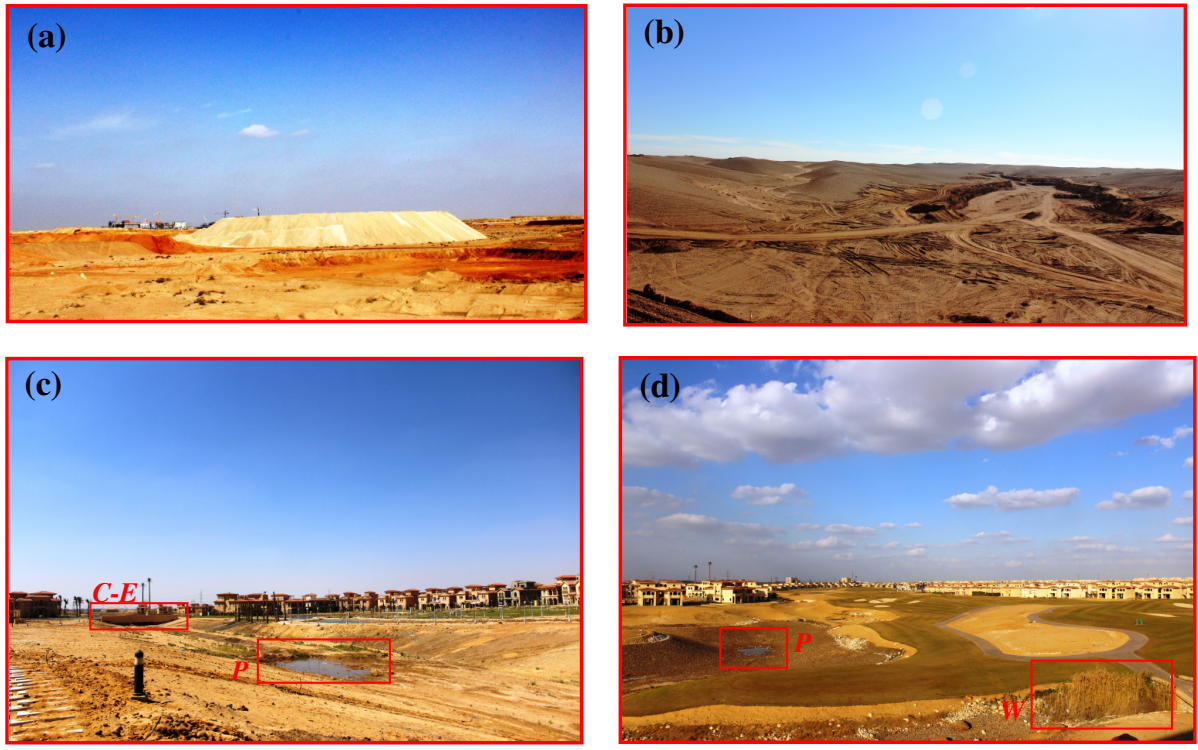

Figure 9. (a) Limestone accumulations blocking Wadi Allawyi, (b) Degradation of Wadi Allawyi upstream, (c) Wadi Anqabiyah crossing the Golf Heights (C-E: culvert-embankment), (d) Artificial topography of the Golf Heights (P: ponds in topographic lows, W: growing natural weeds indside golf hollow). 


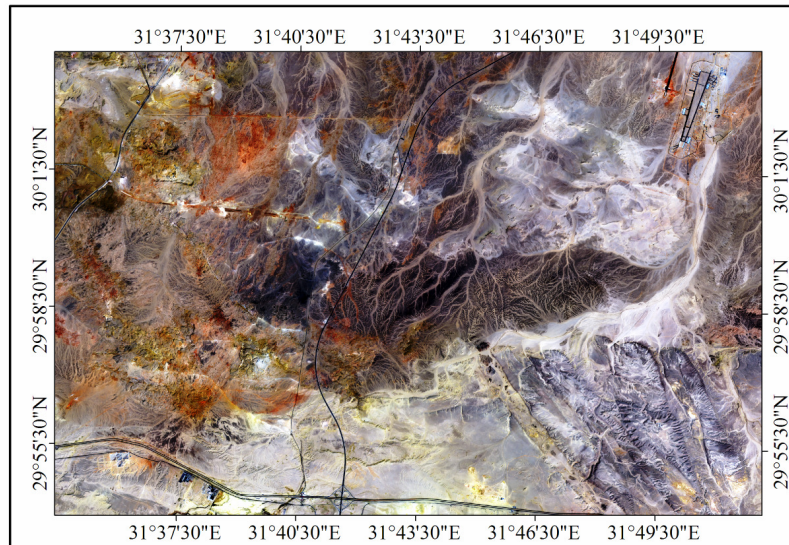

(a) Sentinel-2 satellite image (September 2015)

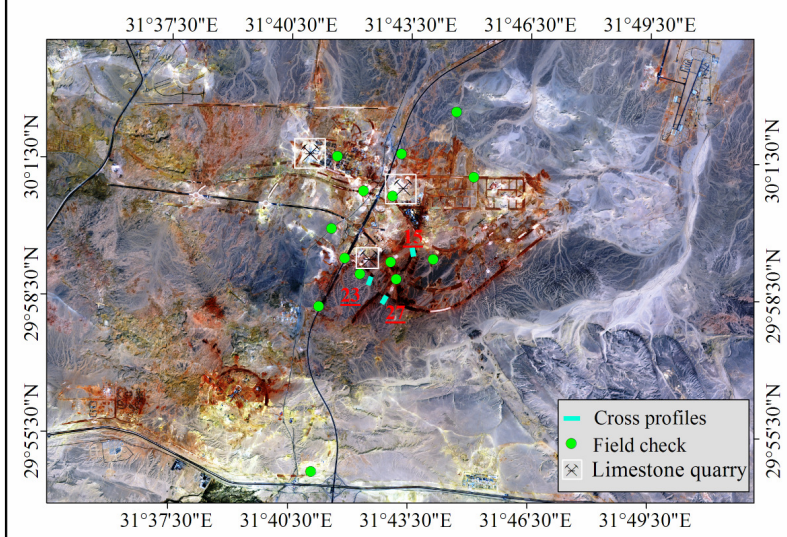

(b) Sentinel-2 satellite image (September 2016)

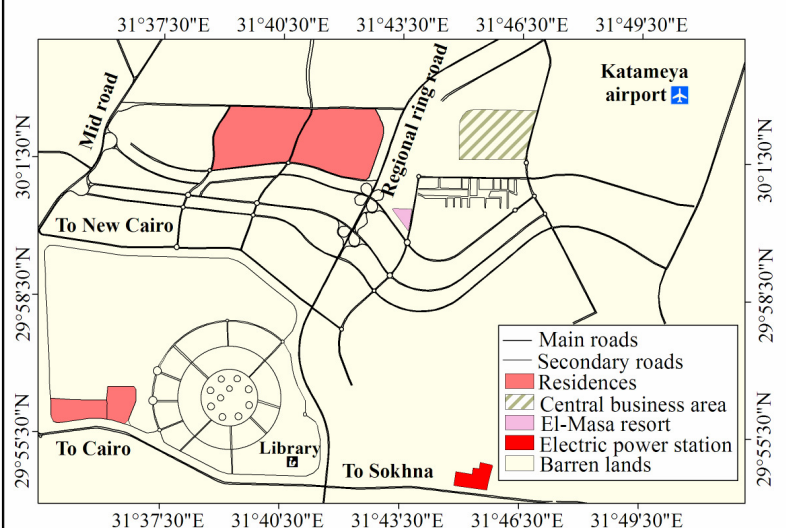

(c) Land use (January 2018)

10 Kilometers

Figure 10. New Administrative Capital.

$-18-$ 

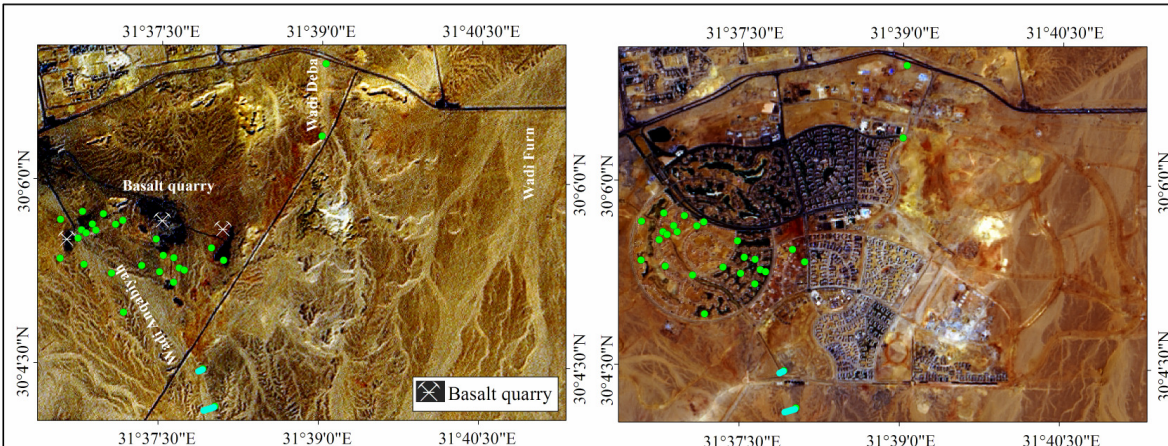

(a) Landsat7 satellite image (November 2000)

(b) Landsat8 satellite image (April 2013)
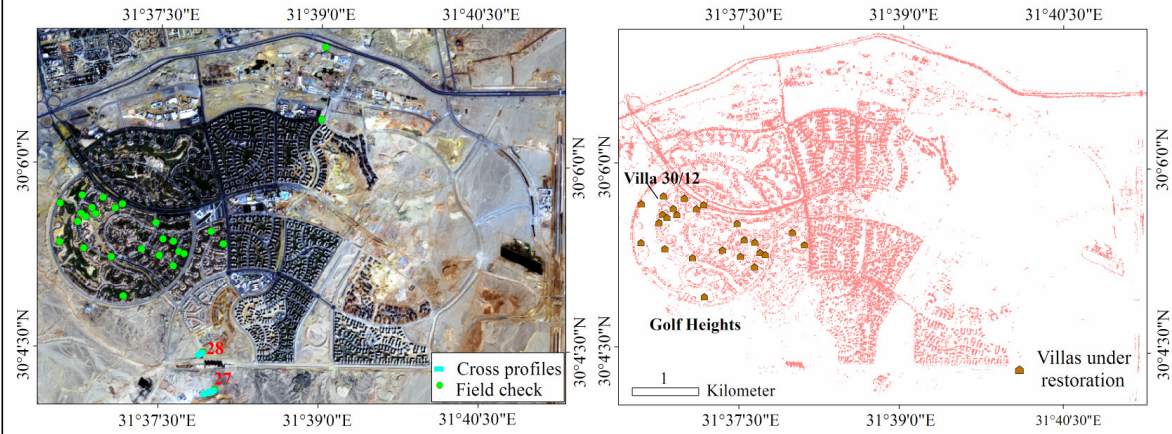

(c) Sentinel-2 satellite image (February 2017)

(d) NDSV (built up area, February 2017=5.4 $\mathrm{km}^{2}$ )
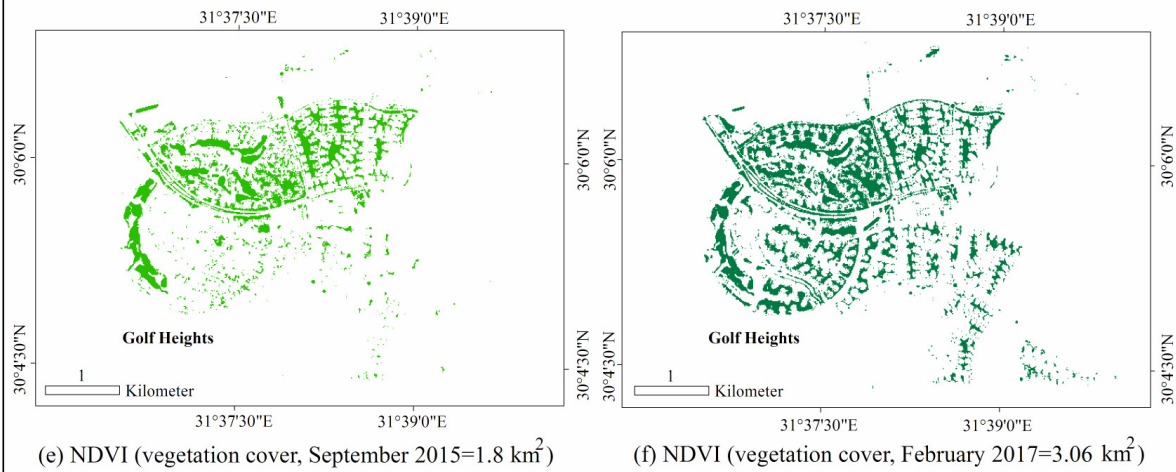

(e) NDVI (vegetation cover, September $2015=1.8 \mathrm{~km}^{2}$ )

(f) NDVI (vegetation cover, February $2017=3.06 \mathrm{~km}^{2}$ )

Figure 11. Urban development of Madinty suburb. 


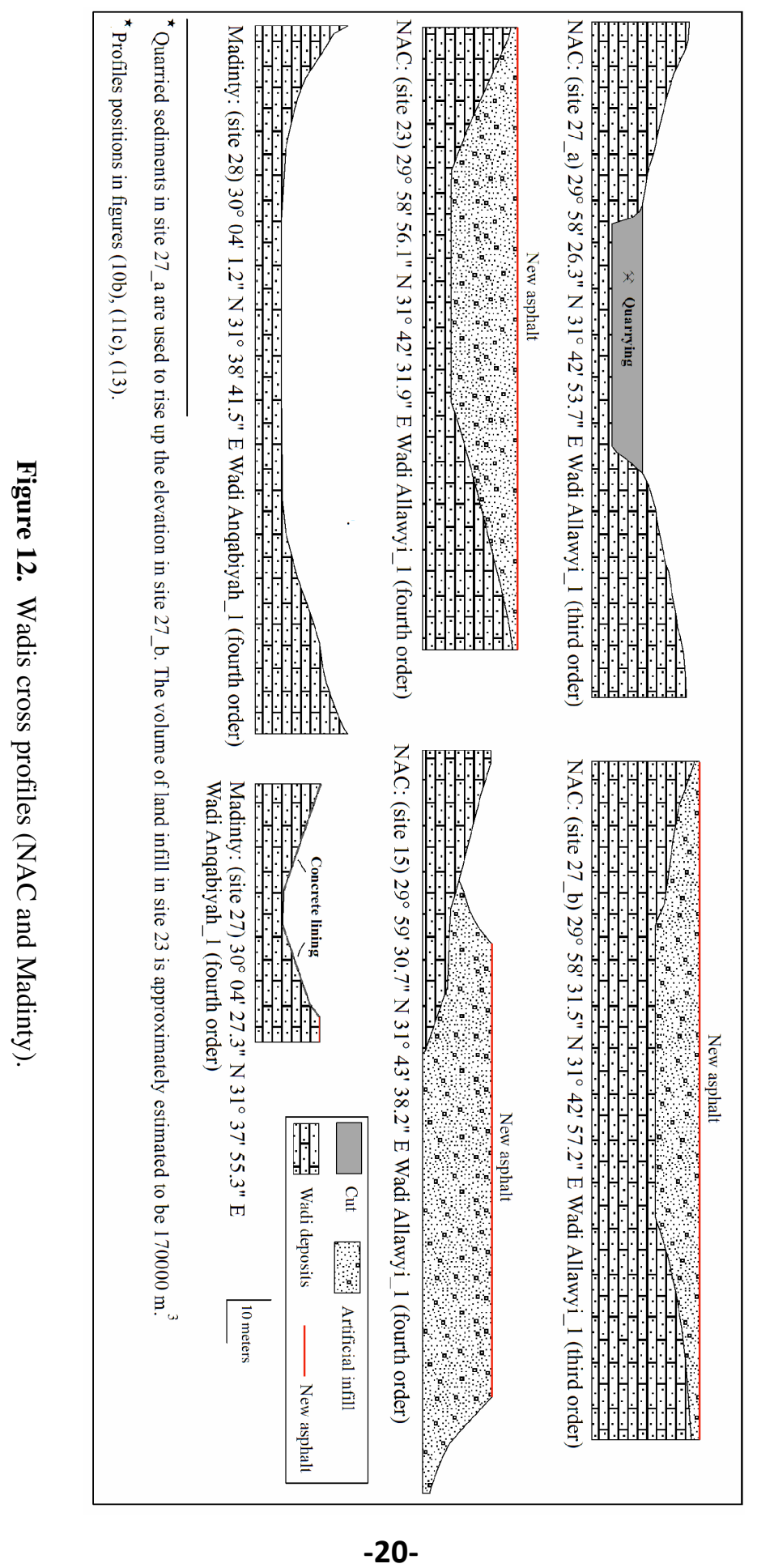




\section{2) Applied Case Studies}

\section{a. Flash floods risk assessment}

The flash flood is one of the most common natural hazards in deserts. It frequently causes economic damage and loss of life. It is concentrated in space, having irregularity and it is unpredictable. Most of the catastrophic flash floods in Egypt are related to recent unmanaged human occupation of wadis. Historically flash flood inundation events were recorded in Cairo City as early as 1895 (Khidr, 1997) and 1915 (Cooke et al., 1982).

The extent of city flood depends on the complex set of interactions between the surface and subsurface drainage networks (i.e. engineering structures) and the urban landscape-landforms including road embankments, walls and buildings (Sene, 2013). Indeed, the mapping of hazard prone area contributes to reducing geomorphic hazards and mitigating human impacts on the landscape (Goudie, 2017). In the term of the flash flood risk, two case studies have been carried out.

In the NAC, the new roads being under construction intersect the main trunk wadis (fourth, fifth and sixth orders) at twenty eight sites in the upper section of Wadi Allawyi-sub1 and Wadi Aburaysha and the lower section of wadi Aljindali (Figure 13). For example, M. Bin Zayed central road meets fourth order wadis at six sites. The main trunk of Wadi Aljindali (a sixth order wadi) is crossed by four main roads. These intersections are high risk spots of potential flash flood inundation. However, the field investigations clarify that the flood engineering measures were absent (May 2017).

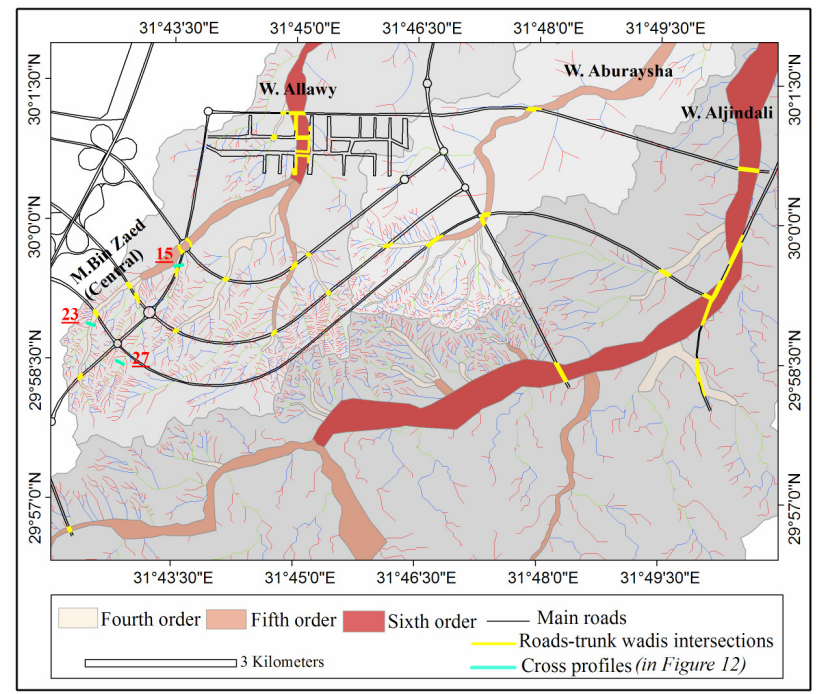

Figure 13. GIS vector-based overlay analysis of flash flood risk in NAC.

-21- 
In Wadi Anasuri (NCC), humans occupy $42 \%$ of the drainage basin. Mostly, $18 \%$ of the built up area in Wadi Anasuri are located in the high and very high risk zones, such as some residential parks which are the most expensive luxury residences in Egypt (Figure 14).

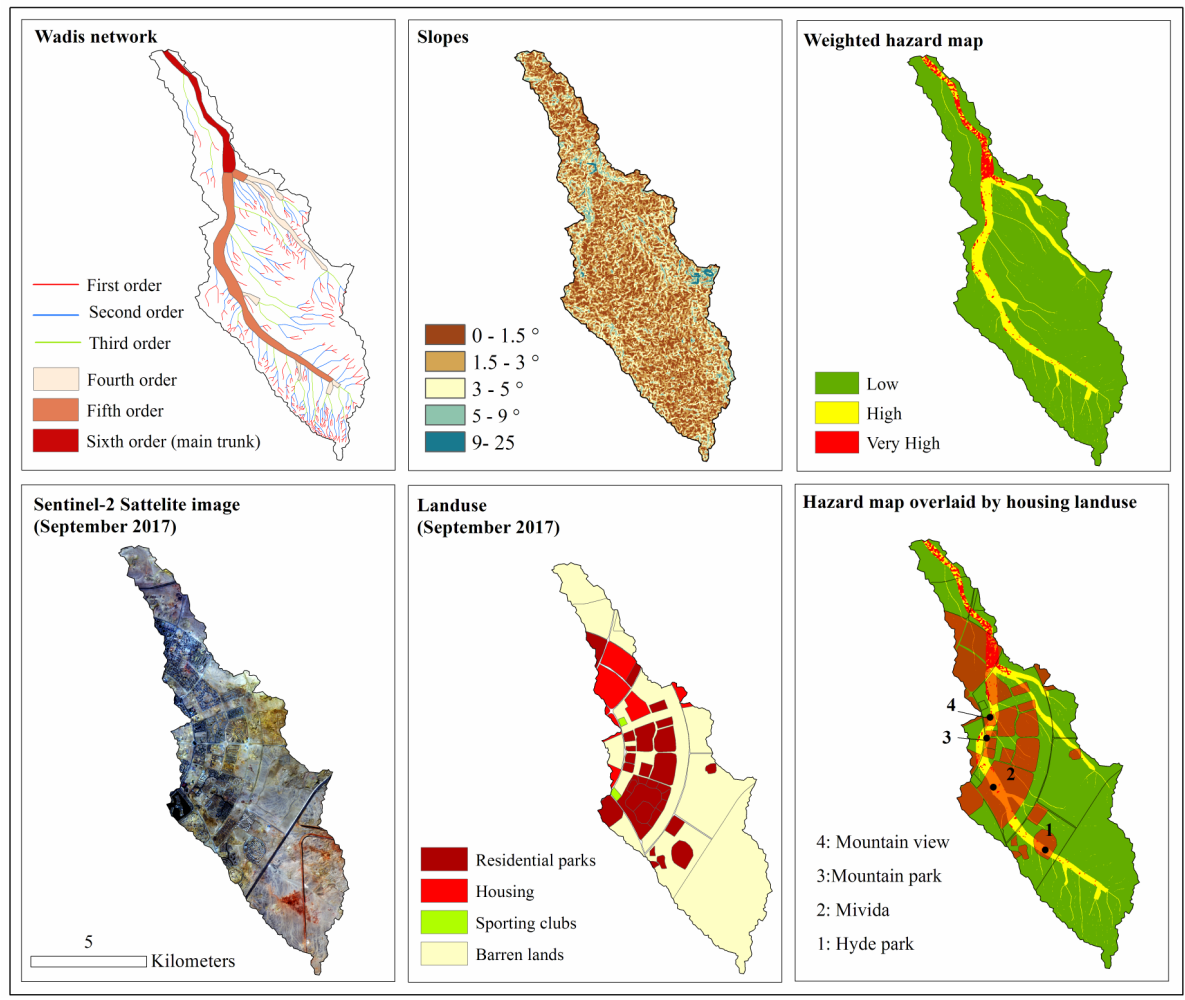

Figure 14. Weighted overly analysis of flash flood risk in Wadi Anasuri (NCC).

\section{The flooding crisis during April 24, 2018}

On 24 April 2018, the GC region witnessed an unusual rainstorm. The rain fell continuously for eight hours (from 6 pm, April 24, 2018 to 2 am, April 25, 2018), with spotty rain pulses over the NCC up to $200 \mathrm{~mm} /$ hour (Figure 15). The field check was carried out on April 25, 2018. That allowed the identification of rain water accumulations (i.e. ponds). Most of these ponds were found on topographic lows (specifically, where some roads cross trunk wadis), for example, Cairo-Suez highway crossing the main trunk of Wadi Umm-risays (30 04' 57.06" N 31 $\left.{ }^{\circ} 28^{\prime} 3.06^{\prime \prime} \mathrm{E}\right)$ and Gamal Abdel-Nasser road crossing the fifth order trunk of Wadi Anasuri $\left(30^{\circ} 01^{\prime} 37.06^{\prime \prime} \mathrm{N} 31^{\circ} 31^{\prime} 42.01^{\prime \prime} \mathrm{E}\right)$. These ponds troubled the whole traffic in the NCC. 
However, the worse accident was recorded in Al-Nargs sub-district. There the upstream tributaries of Wadi Witwat (i.e. the Petrified Forest hilly area, neighbouring Al-Nargs) had flood surface runoff. The Petrified Forest concrete wall blocked flowing water $\left(29^{\circ} 59^{\prime} 57.04^{\prime \prime} \mathrm{N} 31^{\circ} 27^{\prime} 13.05^{\prime \prime} \mathrm{E}\right)$, and after two hours and eyewitness said it partially collapsed. The running water invaded Al-Nargs residence, and yielded a complete inundation of three basements, specifically buildings no. 88, 90 and 92 (Figure 16).

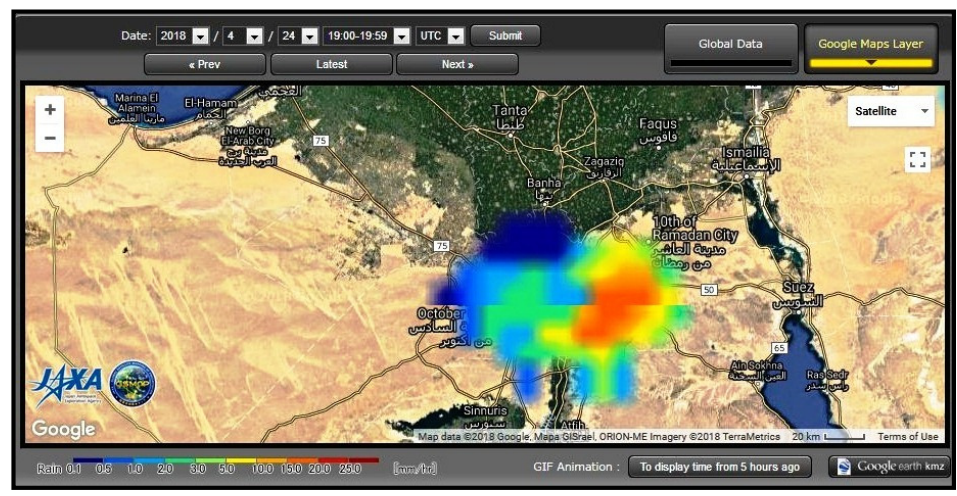

Figure 15. Spotty rainstorm over the NCC (April 24, 2018).

(Source: JAXA Global Rainfall Watch)

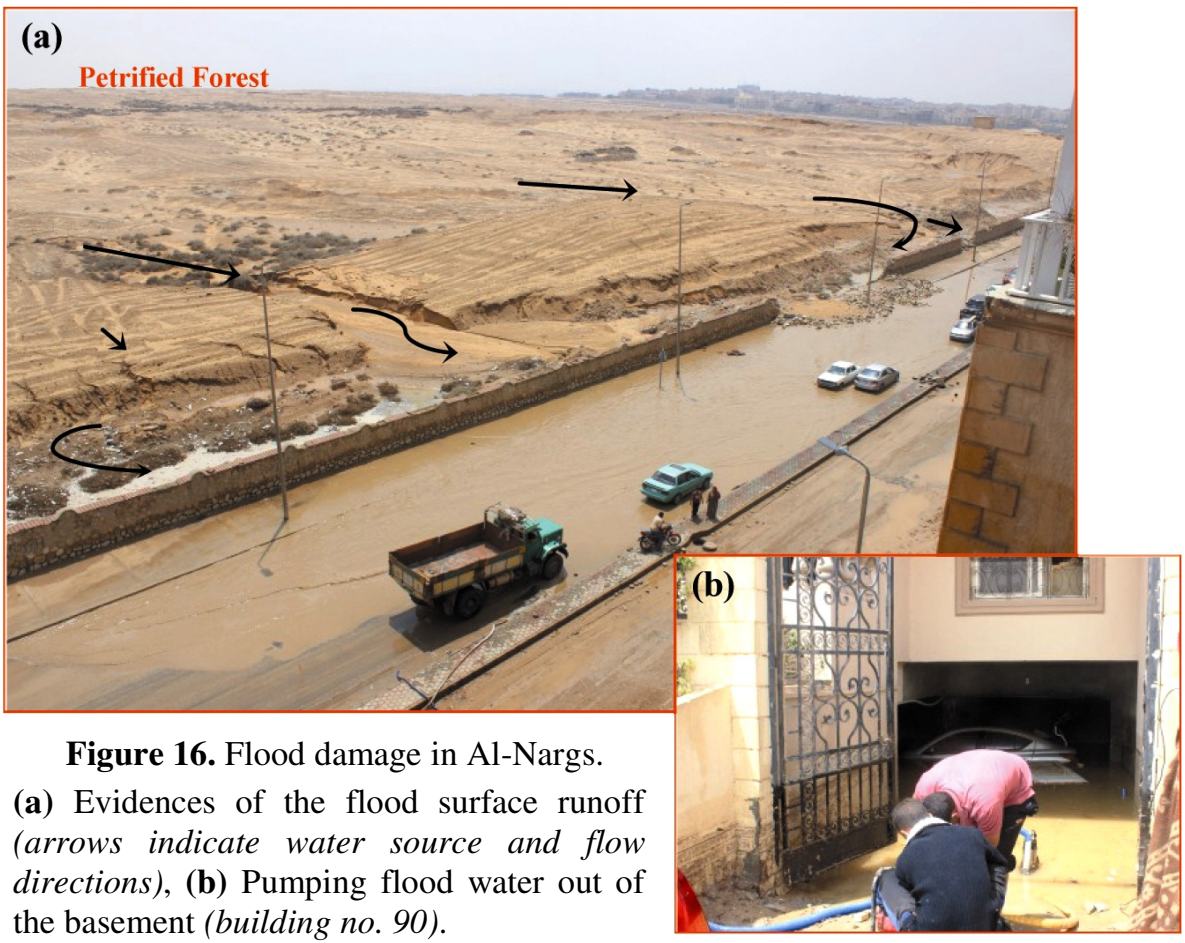

$-23-$ 


\section{b. Land subsidence (a case study in Madinty residence)}

Land subsidence frequently occurred in Madinty residence, causing breakdown of many buildings and asphalt (Figure 17). For example the field survey (December 31,2016) reveals that 25 villas have been repaired due to land subsidence in the Golf Heights district (Figure 11d).
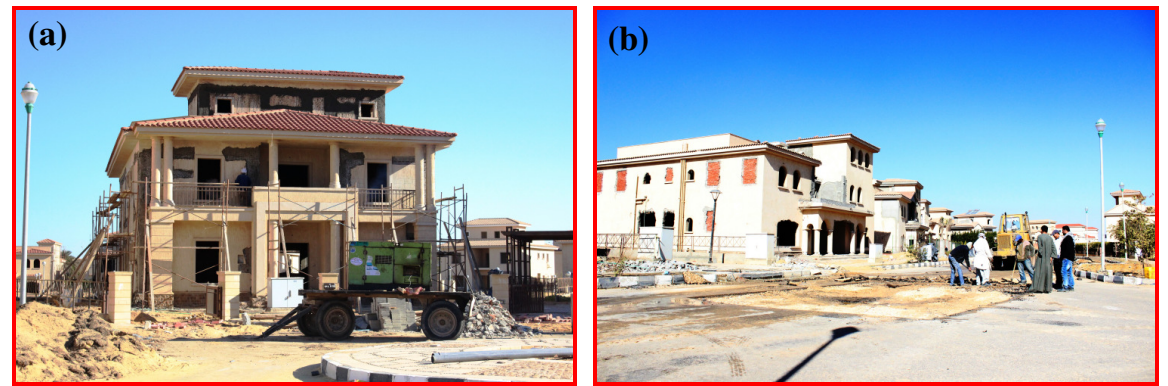

Figure 17. Engineering failure due to land subsidence in Madinty.

(a) Villa under restoration, (b) Street maintenance

The subsurface lithostratigraphy in Madinty (a sub-district B 10, being under construction) mainly consists of sand stone and silt-clay deposits. In subdistrict B10, It is evident that the topmost unit of the core no. 69/5 is composed of artificial infill (Figure 18a). In the Golf Heights sub-district the 1.5 meters of silt-clay deposits is defined below the villa no. 30/12 (Figure 18b). The XRD analysis shows that this unit is enriched in montmorillonite mineral (27.5wt.\%). Also, the artificial infill is well defined in the foundation unit below the villa no. $29 / 12$, which is composed of poorly sorted deposits mixed with broken bricks, wood pieces, metal nails and plastics (Figur 18b).

Before 2006 a large area of Madinty land was used as a basalt quarry, specifically in the Golf Heights (Figure 11a). By the last decade a gradual increase in the built up area, vegetation cover and surface water is observed. The total increase of vegetation cover between 2015 and 2017 equals $1.26 \mathrm{~km}^{2}$, most of that found in the Golf Heights sub-district being under construction (Figures 11e and 11f). There, the use of surface water for irrigation and landscaping (i.e. aquatiq landscaping) yields many ponds in topographic lows, which indicates water infiltiration (Figures 9c and 9d).

With reference to the above mentioned observations, the engineering failure in Madinty may be related to: 1- the mis-selection of the site and reusing the old quarry, 2- mistaken artificial landscaping, 3- the frequent use of surface water coupled with the existence of a permeable sand-stony dposits (including artificial infill) and a high swelling silt-clay deposits. 

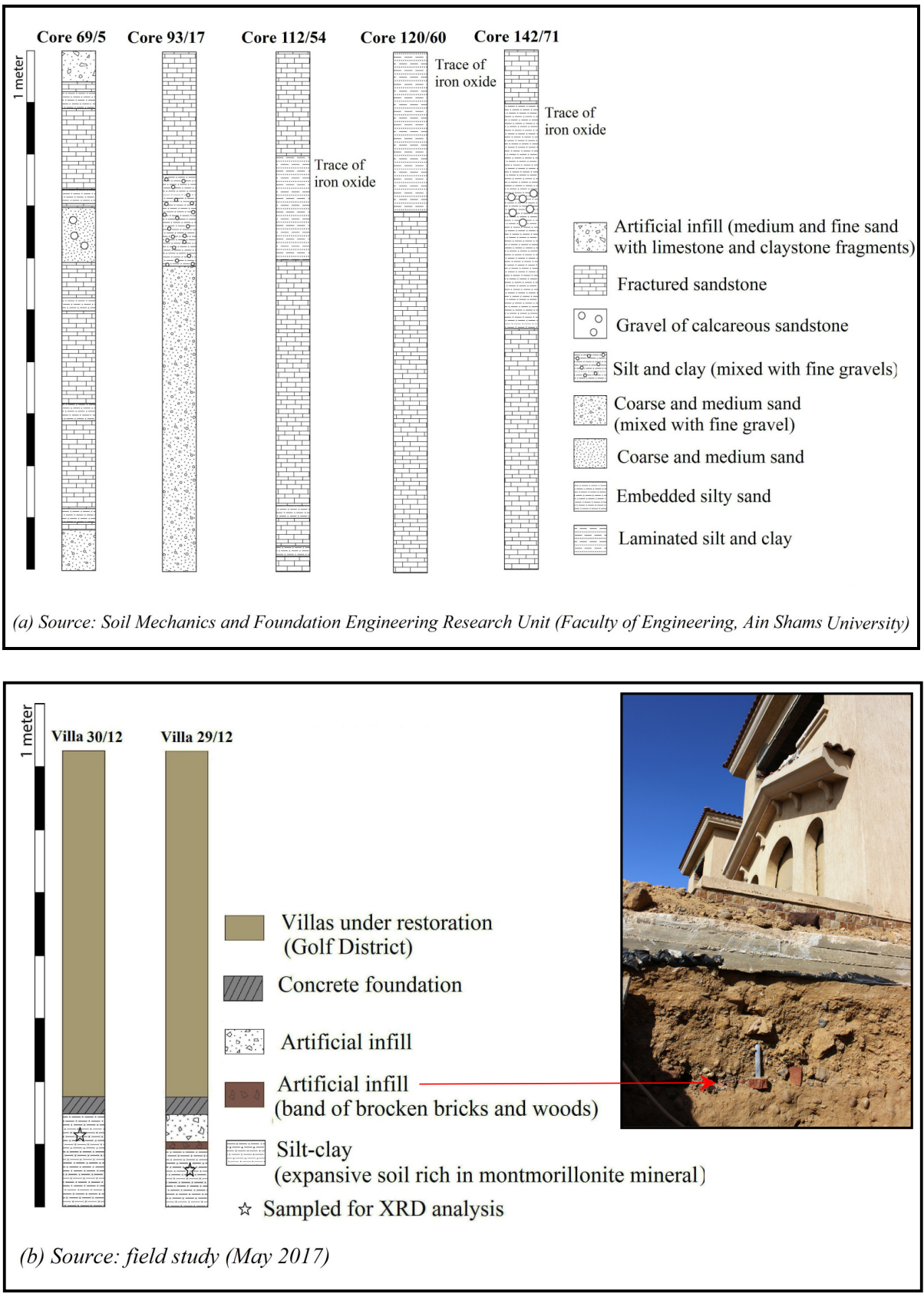

Figure 18. The subsurface lithostratigraphy in Madinty.

\section{$-25-$}




\section{Conclusion}

The urban development east of Greater Cairo causes direct geomorphological changes of the drainage basins. The magnitudes by which natural landforms have changed are a result of urban development stage and size. In the early development stage of the new settlements, Man causes destruction of the micro-scale landforms (e.g. the first order tributaries) and leveling of the natural landscape (positive or negative), as well as the larger scale landforms are clearly modified (e.g. many of the trunk wadis). As the city grows the artificial landforms develop. The man-made landforms are formed at a fast speed, relative to the natural landforms (Jialin et al., 2017). Over the last few years many factors have prompted the formation of the man-made landforms in the study area, such as population-urban growth and political decisions (e.g. establishing the national project of the unnamed NAC).

The misunderstanding of the geomorphologic and topographic setting has caused some crisis in the new suburb east of Greater Cairo (e.g. land subsidence in Madinty residence and flood crisis by the April 24, 2018 in the NCC). The current study underscores the important role of the geomorphologist, mainly for the urban planning during the pre-development stage of the cities.

\section{Acknowledgment}

The author is grateful to Professor Andrew Goudie (Oxford University, UK), for fruitful comments and corrections. Thanks for Mr. Mohamed Elraie (Ain Shams University) for help during the field work.

\section{References}

1. Adeli, Z., Khorshiddoust, A., 2011. Application of geomorphology in urban planning: Case study in landfill site selection. Procedia Social and Behavioral Sciences. 19, 662-667.

2. Al-Awadhi, T., Charabi, Y., Choudri, B., Oraba, b., 2017. Flooding risk analysis: A case study of Muscat Governorate, Sultanate of Oman. Human and Ecological Risk Assessment: An International Journal. DOI: 10.1080/10807039.2017.1396441

3. Angiuli, E., Trianni, G., 2014. Urban mapping in Landsat images based on normalized difference spectral vector. IEEE Geosci. Remote Sens. Lett. 11 (3), 661-665.

4. As-syakur, A., Adnyana, I., Arthana, I., Nuarsa, I., 2012. Enhanced Built-Up and Bareness Index (EBBI) for mapping built-up and bare land in an urban area. Remote Sens. 4, 2957-2970. DOI:10.3390/rs4102957

5. Bajabaa, S., Masouad, M., Alamri, N., 2013. Flash flood hazard mapping based on quantitative hydrology, geomorphology and GIS techniques (case study of Wadi Al Lith, Saudi Arabia). Arab. J. Geosci. 7 (6), 2469-2481. 
6. Bathrellos, G., Karymbalis, H., Skilodimou, H., Gaki-Papanastassiou, K., Baltas, E., 2016. Urban flood hazard assessment in the basin of Athens metropolitan city, Greece. Environ. Earth Sci. DOI 10.1007/s12665-015-5157-1

7. Blasco, J., Verstraetenb, G., Hanssen, R., 2017. Detecting modern desert to urban transitions from space in the surroundings of the Giza World Heritage site and Greater Cairo. J. Cultural Heritage. 23, 71-78.

8. Chen, B., Gong, H., Li, X., Lei, K., Zhu, L., Gao, M., Zhou, C., 2017. Characterization and causes of land subsidence in Beijing, China.

9. Cisma, P., 2010. Urban development and anthropogenic geomorphology. Chapter 12 in Anthropogenic geomorphology (Editors: J. Szabo., L, David., D, Loczy). Dordrecht Springer. p. 179-187.

10. Cooke. R.U., Brunsden, D., Doornkamp. J.C., 1982. Urban Geomorphology in Drylands. Oxford University Press.

11. Costache, R., Zaharia, L., 2017. Flash-flood potential assessment and mapping by integrating the weights-of-evidence and frequency ratio statistical methods in GIS environment - case study: Basca Chiojdului River catchment (Romania). J. Earth Syst. Sci. DOI 10.1007/s12040-017-0828-9

12. Del Monte, M., D’Orefice, M., Luberti, G., Marini, R., Pica, A., Vergari, F., 2016, Geomorphological classification of urban landscapes: the case study of Rome (Italy). J. Maps. 12, 1-12.

13. El-Sawy, E., Ibrahim, A., El-Bastawesy, M., El-Saud, W., 2016. Detection of land use and land cover changes for New Cairo area, using remote sensing and GIS. IJSR. 5 (2), 1186-1197.

14. Esri, Arc GIS Resource Center, 2011. How weighted overlay works. (Online) available at: http://help.arcgis.com/en/arcgisdesktop/10.0/help/index.html\#/How_Weighted_ Overlay_works/009z000000s1000000/

15. Esri, Arc GIS Resource Center, 2012. Hydrologic analysis applications. (Online) available at: http://resources.arcgis.com/en/help/main/10.1/index.html\#//009z0000005z000000

16. Esri, Arc GIS Resource Center, 2014. Slope spatial analyst. (Online) available at: http://resources.arcgis.com/en/help/main/10.2/index.html\#//009z000000v2000000

17. Goodwin, C., Tarboton, D., 2004. Drainage basin and Morphometric properties. In Encyclopedia of Geomorphology (Editor: A. Goudie). Routledge Taylor and Francis.

18. Goudie, A., 2017. The integration of human and physical geography revisited. The Canadian Geographer. 61 (1), 19-27.

19. Hafez, R., 2017. New cities between sustainability and real estate investment: A case study of New Cairo city. HBRC Jour. 13 (1), 89-97.

20. Hereher, M., 2012. Analysis of urban growth at Cairo, Egypt using remote sensing and GIS. Natural Science. 4 (6), 355-361.

21. James, L., Harden, C., Clague, J., 2013. Geomorphology of human disturbances, climate change, and hazards. Treatise on Geomorphology. Academic Press, San Diego. 13, 1-13.

22. Jialin, L., Lei, Y., Ruiliang, P., Yongchao, L., 2017. A review on anthropogenic geomorphology. J. Geogr. Sci. 27(1), 109-128.

23. Khidr, M.M., 1997. The main geomorphological hazards in Egypt (in Arabic). Unpublished M.Sc. Thesis. Department of Geography, Faculty of Arts, Ain Shams University, Cairo, Egypt. 
24. Kumar, V., 2014. Elongation ratio. In Encyclopedia of Snow, ice and glaciers (Editors: J. Singh., P, Singh., U, Haritashya). Springer. DOI 10.1007/978-90-4812642-2

25. Lorant, D., 2012. Introduction to anthropogenic geomorphology. Chapter 11 in Studies on environmental and applied geomorphology, (Editor, T. Piacentini). InTech. p. 267-280. DOI: 10.5772/30583

26. Loughland, R., Al-Abdulkader, K., Wyllie, A., Burwell, b., 2012. Anthropogenic induced geomorphological change along the western Arabian Gulf coast. Chapter 8 in Studies on environmental and applied geomorphology, (Editor, T. Piacentini). InTech. p. 192-218. DOI: 10.5772/28330

27. Marouard, G., 2014. Kom el-Dahab interpreted. Egyptian Archaeology. 45, 25-27.

28. Mohapatra, S., Pani, P., Sharma, M., 2014. Rapid urban expansion and its implications on geomorphology: a remote sensing and GIS based study. Geography Journal. (Online) available at: http://dx.doi.org/10.1155/2014/361459

29. Moustafa, A., Abd-Allah, A., 1991. Structural setting of the central part of the Cairo-Suez district. M.E.R.C. Ain Shams Univ. Earth Sci. 5, 133-145.

30. Moustafa, A., EL-Nahhas, F., Abdel Tawab, S., 1991. Engineering geology of Mokattam city and vicinity, eastern Greater Cairo, Egypt. Engineering geology. 31, 327-344.

31. Said, R., 1962. The Geology of Egypt. Amsterdam, Elsevier.

32. Schumm, S.A., 1956. The evolution of drainage systems and slopes in Badlands at Perth Amboy, New Jersey. Bull. Geol. Soc. Am. Bull. 67(5), 597646.

33. Sene, K., 2013. Urban Flooding. Chapter 10 in Flash floods (forecasting and warning). Springer. DOI 10.1007/978-94-007-5164-4

34. Sims, D., 2010. Understanding Cairo: the logic of a city out of control. The American University in Cairo press.

35. Strahler, A.N., 1957. Quantitative analysis of watershed geomorphology. Am. Geophys. Uni. Trans. 38, 913- 920.

36. Szabo, J., 2010. Anthropogenic geomorphology: subject and system. Chapter 1 in Anthropogenic geomorphology (Editors: J. Sazbo., L, David., D, Loczy). Dordrecht Springer. p. 3-10.

37. Wainwright, J., Bracken, J.B., 2011. Runoff generation, overland flow and erosion on hillslopes. Chapter 11 in Arid zone geomorphology: process, form and change in drylands, third Edition, (Editor: D.S. Thomas). John Wiley \& Sons. p. 237-267.

38. World urbanization prospect, 2018, United Nations, Department of Economic and Social Affairs, population division. (Online) available at: https://esa.un.org/unpd/wup/

39. $\mathrm{Xu}, \mathrm{H} ., 2$ 2006. Modification of normalized difference water index (NDWI) to enhance open water features in remotely sensed imagery. Int. J. Remote Sens. 27 (14), 3025-3033

40. Yi, Y., Zhao, Y., Ding, G., Gao, G., Shi, M., Cao, Y., 2016. Effects of urbanization on landscape patterns in a mountainous Area: a case study in the Mentougou district, Beijing, China. Sustainability. DOI: 10.3390/su811119

41. Zha, Y., Gao, J., Ni, S., 2003. Use of normalized difference built-up index in automatically mapping urban areas from TM imagery. Int. J. Remote Sens. 24 (3), 583-594. 